\title{
The relationship between drainage density and soil erosion rate: a study of five watersheds in Ardebil Province, Iran
}

\author{
A. Moeini ${ }^{1}$, N. K. Zarandi ${ }^{1}$, E. Pazira ${ }^{1}$ \& Y. Badiollahi ${ }^{2}$ \\ ${ }^{I}$ Department of Watershed Management, College of Agriculture \\ and Natural Resources, Science and Research Branch, \\ Islamic Azad University, Iran \\ ${ }^{2}$ University College of Nabie Akram (UCNA), Iran
}

\begin{abstract}
Drainage density is one of the parameters that can be considered as an indicator of erosion rate. This study analysed the relationship between drainage density and soil erosion in five watersheds in Iran. The drainage density was measured using satellite images, aerial photos, and topographic maps by Geographic Information Systems (GIS) technologies. MPSIAC model was employed in a GIS environment to create soil erosion maps using data from meteorological stations, soil surveys, topographic maps, satellite images and results of other relevant studies. Then the correlation between drainage density and erosion rate was measured. The mean soil loss rate in the study areas were 1 to $6.43 \mathrm{t} \cdot \mathrm{h}^{-1} \cdot \mathrm{y}^{-1}$ and drainage density values varied 1.44 to $5.43 \mathrm{Km} \mathrm{Km}^{-1}$. The results indicate that the relationship between these two factors improved when the types of sheet erosion, mechanical erosion and mass erosion was ignored because these types of erosion were not mainly influenced by the power of runoff. There was a high correlation between drainage density and erosion in most of the watersheds. Finally a significant relationship was seen between drainage density and erosion in all watersheds. Based on the results obtained, the present method for distinguishing soil erosion was effective and can be used for operational erosion monitoring in other watersheds with the same climate characteristics in Iran. Keywords: surface erosion, drainage density, MPSIAC model, GIS.
\end{abstract}




\section{Introduction}

Soil erosion by water plays an important role in the process of land degradation and is linked to a number of environmental and socioeconomic problems worldwide. The effects of water erosion can be observed both on-site and offsite. On-site impacts are important in soils for agriculture, which leads to greater applying fertilizers and later may cause the abandonment of agriculture. The offsite impacts creates different problems associated with the deposition and consolidation of sediments in reservoirs, navigation canals, storm water pipes systems, retention ponds, floodplains, etc. [1]. Factors affecting water erosion and sediment production in the basin include: Types of geological formations, weather and climate, soil, topography, vegetation and land use. One of the parameters that can be regarded as an indicator of erosion is drainage density, which is the total length of streams per unit area of the watershed and depends on the factors such as lithology, permeability, vegetation. Drainage density varies in different tissues and depends on the soil type [2]. A study on erosion in geomorphology facies done by Ahmadi et al. [3] stated the relationship between the density of drainage and erosion. Spatial analysis of drainage network was performed by using GIS by Mishra [4]. During the study, priority areas for erosion control [5] and surface erosion and drainage basin development [6] were investigated. The effect of type of drainage on reduction and storage of surface runoff and capacity of the soil was reviewed by Irwin and Whiteley [7]. The aim of this study was to examine the relationship between drainage density and intensity of erosion in the different watersheds of Ardebil province.

\section{Materials and methods}

\subsection{Sites description}

A. Narghashlaghy watershed with the area of $4,548.09$ hectares is in the northern city of Ardebil and with coordinates, $47^{\circ}, 59^{\prime}, 8^{\prime \prime}$ to $48^{\circ}, 6^{\prime}, 10^{\prime \prime}$ east longitude and $39^{\circ}, 12^{\prime}, 22^{\prime \prime}$ to $39^{\circ}, 16^{\prime}, 7^{\prime \prime}$ the north latitude.

B. Bargchay watershed of MeshkinShahr with the area of 4,541.7 hectares, located in the north of Razi, one city of the Ardabil province, in geographic coordinates $48^{\circ}, 0^{\prime}, 37^{\prime \prime}$ to $48^{\circ}, 9^{\prime}, 48^{\prime \prime}$ east longitude and $38^{\circ}, 39^{\prime}, 56^{\prime \prime}$ to $38^{\circ}, 46^{\prime}, 16^{\prime \prime}$ the north latitude.

C. Siahpoush watershed with the area of $10,103.4$ hectares is one of the southern cities of Ardebil located in geographic coordinates $48^{\circ}, 6^{\prime}, 35^{\prime \prime}$ to $48^{\circ}, 16^{\prime}, 46^{\prime \prime}$ east longitude and $37^{\circ}, 46^{\prime}, 8^{\prime \prime}$ to $37^{\circ}, 54^{\prime}, 0$ " north latitude.

D. Saghezchichay watershed with the area of 6,607 hectares with coordinates $47^{\circ}, 54^{\prime}, 7^{\prime \prime}$ to $48^{\circ}, 42^{\prime}, 44^{\prime \prime}$ east longitude and $38^{\circ}, 9^{\prime}, 11^{\prime \prime}$ to $38^{\circ}, 16^{\prime}$, and 53 " north latitude is located in the eastern of Ardabil.

E. Alucheh-Fuladlu watershed with the area of 5,466.1 hectares is located in the south east of Ardebil with coordinates $48^{\circ}, 7^{\prime}, 21^{\prime \prime}$ to $48^{\circ}, 25^{\prime}, 56^{\prime \prime}$ east longitude and $38^{\circ}, 58^{\prime}, 6^{\prime \prime}$ to $38^{\circ}, 6^{\prime}, 2^{\prime \prime}$ north latitude. 


\subsection{Methods}

The drainage density was measured using satellite images, aerial photos, and topographic maps by Geographic Information Systems (GIS) technologies. The MPSIAC model was employed in a GIS environment to create soil erosion maps using data from meteorological stations, soil surveys, topographic maps, satellite images and results of other relevant studies. Then the correlation between drainage density and erosion rate was measured. The following equation was used to calculate the drainage density.

$$
D=\frac{\sum L}{A}
$$

where $\Sigma \mathrm{L}$ is the total length of the hydrographic network $(\mathrm{km})$ and $\mathrm{A}$ is the hydrographic basin area $\left(\mathrm{km}^{2}\right)$.

The MPSIAC model was used for erosion estimation. This model was created to estimate the soil erosion according to nine factors consisting of, geological characteristics, soil, climate, runoff, topography, vegetation cover, land use and present soil erosion (PSIAC, 1968). Johnson and Gembhart (1982) improved the original model to have a more accurate estimate of the sedimentation (eqn 2).

$$
\mathrm{QS}=25.3 * \mathrm{e}^{\wedge} .036 * \mathrm{R}
$$

where QS is sedimentation ( $\mathrm{t} / \mathrm{km}^{2} /$ year), $\mathrm{R}$ is sedimentation rate and $\mathrm{e}=2.718$.

Table 1: MPSIAC nine factors in erosion types of different studied watersheds.

\begin{tabular}{lll}
\hline No. & Description & Relationship \\
\hline 1 & $\mathrm{X}_{1}$ : stone sensitive point & $\mathrm{Y} 1=\mathrm{x} 1$ \\
2 & $\mathrm{X}_{2}$ : erodibility factor in USLE & $\mathrm{Y} 2=16.67 \times 2$ \\
3 & $\mathrm{X}_{3}$ : precipitation intensity with 2 year interval return & $\mathrm{Y} 3=0.2 \times 3$ \\
& $\mathrm{X}_{4}$ : annual runoff depth (mm), Qp: annual specific & $\mathrm{Y} 4=0.2(0.006$ \\
& discharge & $\mathrm{R}+10 \mathrm{QP})$ \\
5 & $\mathrm{X}_{5}$ : average watershed slope (\%) & $\mathrm{Y} 5=0.33 \times 5$ \\
6 & $\mathrm{X}_{6}$ : bare soil (\%) & $\mathrm{Y} 6=0.2 \times 6$ \\
7 & $\mathrm{X}_{7}$ : canopy cover (\%) & $\mathrm{Y} 7=20-0.2 \times 7$ \\
8 & $\mathrm{X}_{8}$ : points summation in BLM model & $\mathrm{Y} 8=0.25 \times 8$ \\
9 & $\mathrm{X}_{9}$ : point of Gully erosion in BLM model & $\mathrm{Y} 9=1.67 \times 9$ \\
\hline
\end{tabular}

\section{Results}

By calculating drainage density and erosion rate in studied watersheds, the following information was obtained: 
Table 2: Relationship between drainage density and erosion in Narghashlaghi watershed.

\begin{tabular}{|c|c|c|c|}
\hline Erosion types & Area $\left(\mathrm{km}^{2}\right)$ & $\begin{array}{c}\text { Drainage density } \\
\left(\mathrm{km} / \mathrm{km}^{2}\right)\end{array}$ & $\begin{array}{c}\text { Erosion } \\
\left(\mathrm{TON} / \mathrm{km}^{2} / \mathrm{Y}\right)\end{array}$ \\
\hline $\mathrm{S}_{1} \mathrm{R}_{1}$ & 3.97 & 3.42 & 129 \\
\hline $\mathrm{S}_{2} \mathrm{R}_{1} \mathrm{~W}_{1}$ & 4.84 & 1.44 & 208 \\
\hline $\mathrm{S}_{2} \mathrm{R}_{2} \mathrm{~W}_{1}$ & 12.30 & 2.89 & 250 \\
\hline $\mathrm{S}_{2} \mathrm{R}_{2} \mathrm{~W}_{2}$ & 8.04 & 2.09 & 249 \\
\hline $\mathrm{S}_{3} \mathrm{R}_{3} \mathrm{~W}_{2}$ & 11.24 & 1.57 & 282 \\
\hline $\mathrm{S}_{3} \mathrm{R}_{3} \mathrm{~W}_{3} \mathrm{M}_{1}$ & 5.11 & 2.44 & 375 \\
\hline
\end{tabular}

Table 3: Relationship between drainage density and erosion in Bargchay watershed.

\begin{tabular}{|c|c|c|c|}
\hline Erosion types & Area $\left(\mathrm{km}^{2}\right)$ & $\begin{array}{c}\text { Drainage density } \\
\left(\mathrm{km} / \mathrm{km}^{2}\right)\end{array}$ & $\begin{array}{c}\text { Erosion } \\
\left(\mathrm{TON} / \mathrm{km}^{2} / \mathrm{Y}\right)\end{array}$ \\
\hline $\mathrm{S}_{3} \mathrm{M}_{2}$ & 7.05 & 3.88 & 420 \\
\hline $\mathrm{S}_{4} \mathrm{R}_{2}$ & 10.51 & 4.76 & 643 \\
\hline $\mathrm{S}_{2} \mathrm{R}_{1}$ & 10.53 & 3.32 & 271 \\
\hline $\mathrm{S}_{3} \mathrm{R}_{1}$ & 5.85 & 4.02 & 365 \\
\hline $\mathrm{S}_{3} \mathrm{M}_{1}$ & 11.46 & 4.75 & 384 \\
\hline
\end{tabular}

Table 4: Relationship between drainage density and erosion in Siahpoush watershed.

\begin{tabular}{|c|c|c|c|}
\hline Erosion types & Area $\left(\mathrm{km}^{2}\right)$ & $\begin{array}{c}\text { Drainage density } \\
\left(\mathrm{km} / \mathrm{km}^{2}\right)\end{array}$ & $\begin{array}{c}\text { Erosion } \\
\left(\mathrm{TON} / \mathrm{km}^{2} / \mathrm{Y}\right)\end{array}$ \\
\hline $\mathrm{S}_{3} \mathrm{R}_{3}$ & 33.82 & 3.33 & 463 \\
\hline $\mathrm{S}_{2}$ & 2.87 & 2.8 & 100 \\
\hline $\mathrm{S}_{3} \mathrm{R}_{3} \mathrm{LS}_{1}$ & 32.03 & 2.88 & 63 \\
\hline $\mathrm{S}_{2} \mathrm{R}_{3} \mathrm{LS}_{2}$ & 14.09 & 3.4 & 425 \\
\hline $\mathrm{S}_{3} \mathrm{R}_{2} \mathrm{~W}_{3} \mathrm{LS}_{2}$ & 7.78 & 4.42 & 618 \\
\hline $\mathrm{S}_{3} \mathrm{R}_{3} \mathrm{~W}_{2} \mathrm{LS}_{2}$ & 6.92 & 4.56 & 335 \\
\hline
\end{tabular}

Table 5: Relationship between drainage density and erosion in Saghezchichay watershed.

\begin{tabular}{|c|c|c|c|}
\hline Erosion types & Area $\left(\mathrm{km}^{2}\right)$ & $\begin{array}{c}\text { Drainage density } \\
\left(\mathrm{km} / \mathrm{km}^{2}\right)\end{array}$ & $\begin{array}{c}\text { Erosion } \\
\left(\mathrm{TON} / \mathrm{km}^{2} / \mathrm{Y}\right)\end{array}$ \\
\hline $\mathrm{S}_{1} \mathrm{R}_{1}$ & 5.86 & 4.51 & 130 \\
\hline $\mathrm{S}_{2} \mathrm{R}_{2} \mathrm{~W}_{1}$ & 8.71 & 2.80 & 149 \\
\hline $\mathrm{S}_{2} \mathrm{R}_{1} \mathrm{~W}_{1} \mathrm{M}_{1}$ & 7.41 & 3.71 & 171 \\
\hline $\mathrm{S}_{2} \mathrm{R}_{2} \mathrm{~W}_{2} \mathrm{M}_{2}$ & 16.90 & 3.84 & 264 \\
\hline $\mathrm{S}_{3} \mathrm{R}_{3}$ & 19.69 & 3.22 & 231 \\
\hline $\mathrm{S}_{3} \mathrm{R}_{2} \mathrm{~W}_{1} \mathrm{M}_{2}$ & 5.01 & 3.27 & 236 \\
\hline
\end{tabular}


Table 6: Relationship between drainage density and erosion in AluchehFuladlu watershed.

\begin{tabular}{|c|c|c|c|}
\hline Erosion types & Area $\left(\mathrm{km}^{2}\right)$ & $\begin{array}{c}\text { Drainage density } \\
\left(\mathrm{km} / \mathrm{km}^{2}\right)\end{array}$ & $\begin{array}{c}\text { Erosion } \\
\left(\mathrm{TON} / \mathrm{km}^{2} / \mathrm{Y}\right)\end{array}$ \\
\hline $\mathrm{S}_{1}$ & 2.62 & 5.43 & 103 \\
\hline $\mathrm{S}_{1} \mathrm{R}_{1}$ & 16.58 & 4.23 & 163 \\
\hline $\mathrm{S}_{2} \mathrm{R}_{1} \mathrm{M}_{1}$ & 5.15 & 3.18 & 153 \\
\hline $\mathrm{S}_{2} \mathrm{R}_{2} \mathrm{Gu}_{1}$ & 3.02 & 4.22 & 200 \\
\hline $\mathrm{S}_{3} \mathrm{R}_{2} \mathrm{~W}_{1}$ & 6.81 & 5.03 & 316 \\
\hline $\mathrm{S}_{3} \mathrm{R}_{3} \mathrm{~W}_{2} \mathrm{M}_{2}$ & 2.48 & 4.21 & 491 \\
\hline
\end{tabular}

(S: surface, R: rill, W: Channel, Gu: gully, M: mechanical, LS: land slide (mass movement) erosion and numbers present erosion intensity).

First, by the statistical analysis using SPSS software and charting the drainage density and erosion, it was observed that there is not a significant linear relationship between the drainage density and erosion.

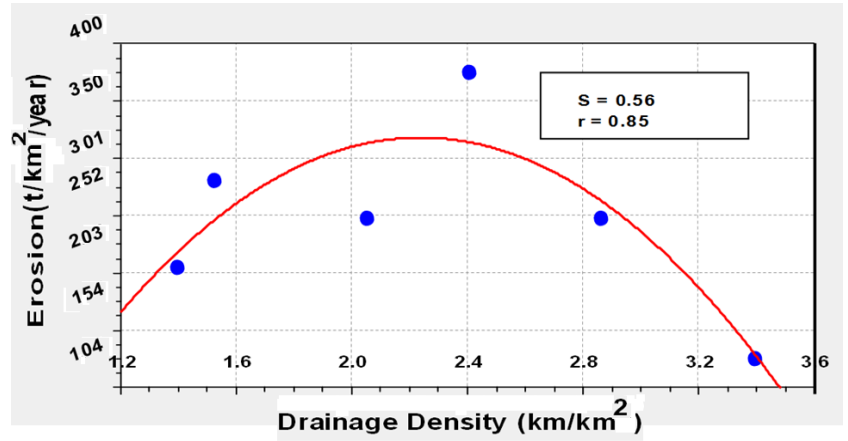

Figure 1: Relation between drainage density and erosion in watershed.

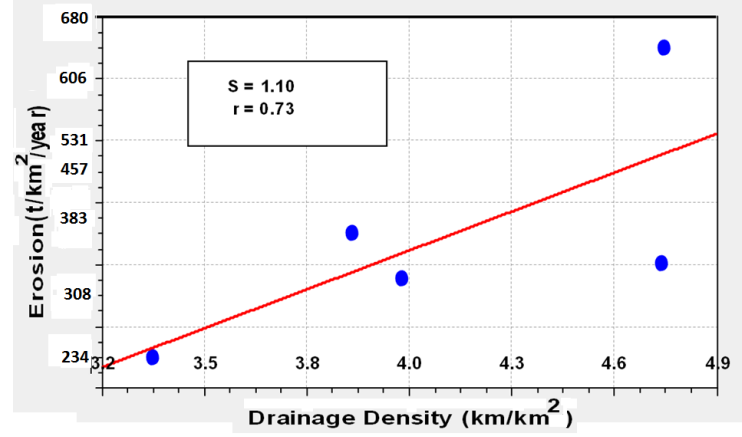

Figure 2: Relation between drainage density and erosion in Bargchay watershed. 


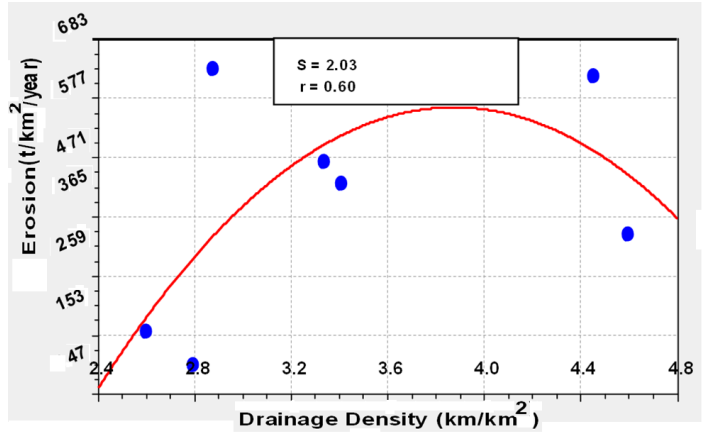

Figure 3: Relation between drainage density and erosion in Siahpoush watershed.

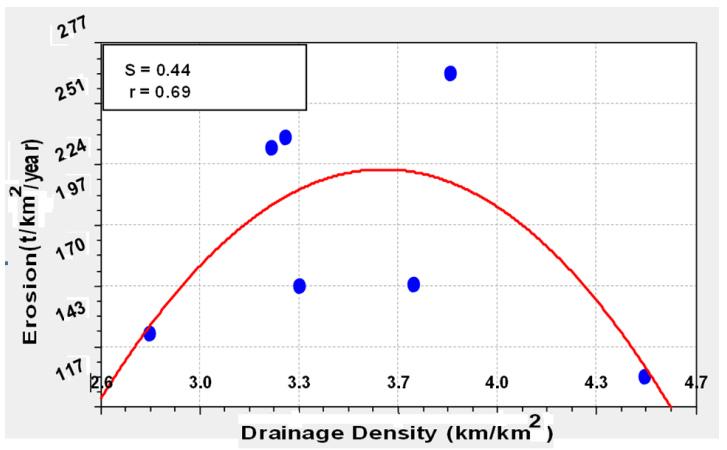

Figure 4: Relation between drainage density and erosion in Saghezchichay watershed.

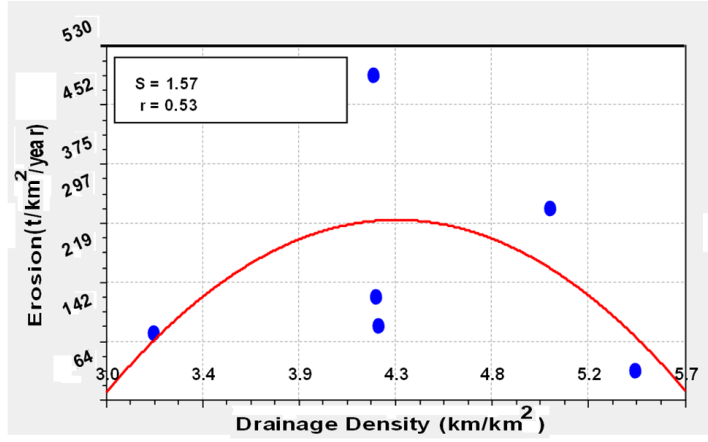

Figure 5: Relation between drainage density and erosion in Alucheh-Fuladlu watershed. 
Since there is no relation between drainage density and mechanical, mass and surface erosion, then surface erosion in the Narghashlaghi watershed, surface erosion and weak mechanical in the Bargchay watershed, medium surface erosion and land slide (mass) in the Siahpoush watershed, weak surface erosion in the Saghezchichay watershed, poor surface erosion in the Alucheh-Fuladlu watershed, have not been considered.

With statistical analysis using SPSS software and charting drainage density and erosion, it was observed that the linear correlation between the drainage density and erosion is created.

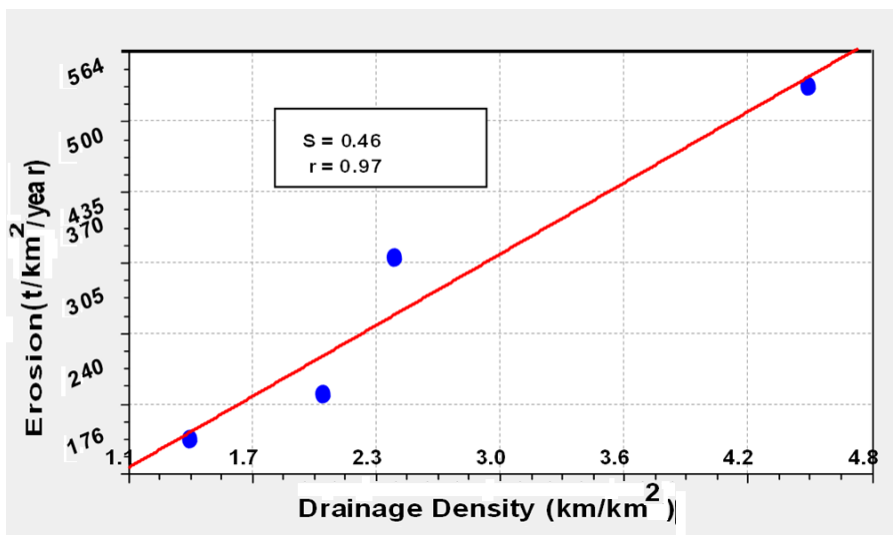

Figure 6: Relation between drainage density and erosion in Narghashlaghi watershed.

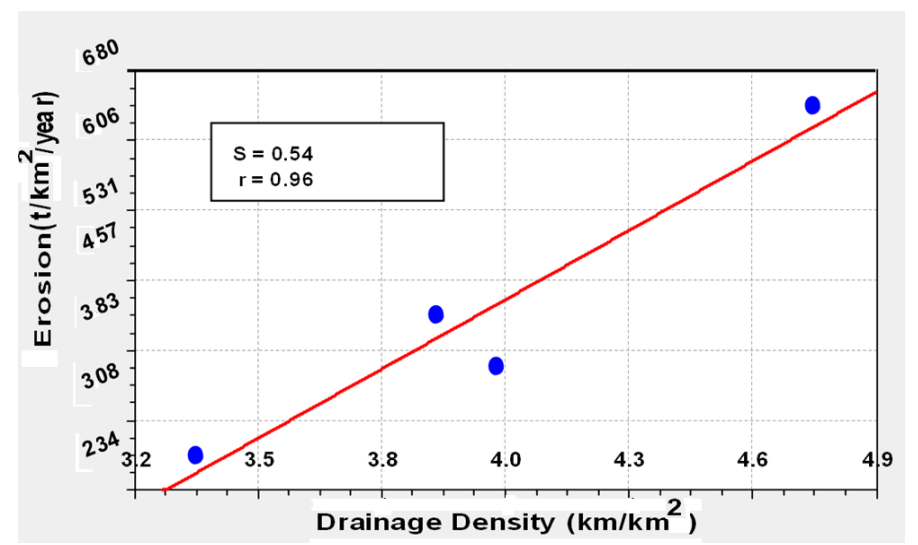

Figure 7: Relation between drainage density and erosion in Bargchay watershed. 


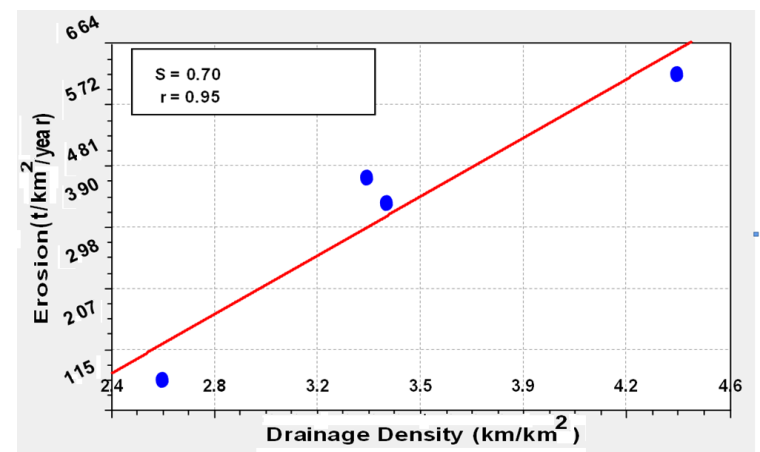

Figure 8: Relation between drainage density and erosion in Siahpoush watershed.

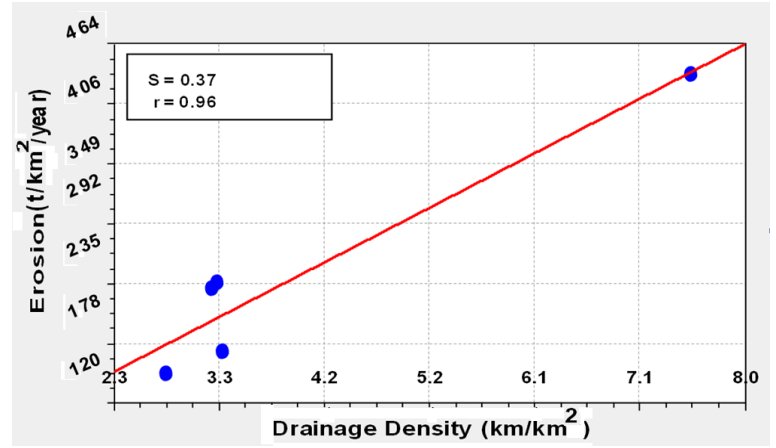

Figure 9: Relation between drainage density and erosion in Saghezchichay watershed.

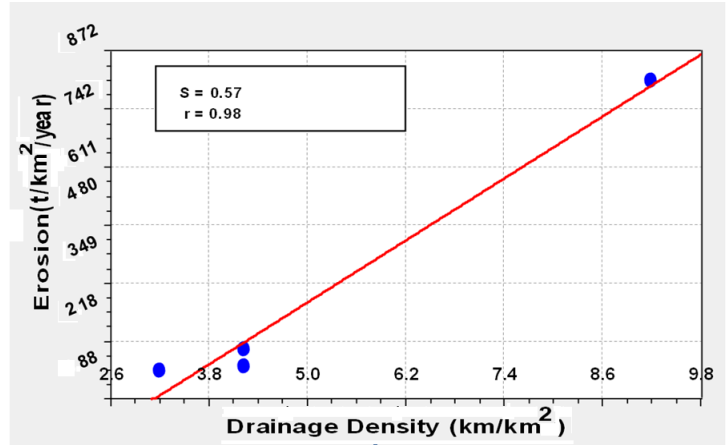

Figure 10: Relation between drainage density and erosion in Alucheh-Fuladlu watershed. 
With statistical analysis using SPSS software and charting drainage density and erosion in all watersheds, it was observed that there is a linear correlation between the drainage density and erosion.

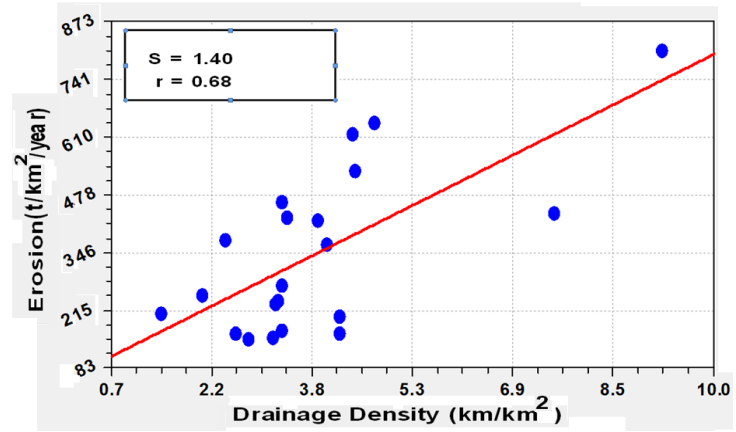

Figure 11: Relation between drainage density and erosion in all mentioned watershed.

\section{Conclusion}

Drainage density is an important factor that affects erosion process. Therefore, its management can cause erosion control in the region. Drainage density depends on soil type and amount of flow through the channel, that is compatible with results of Germanoski et al. [2] who compared the drainage density in areas with different textures (shale, slate) in East Pennsylvania. Drainage density has not any role in the surface, mechanical and mass erosion, because these types of erosion was not be affected by stream. Finally, there is a significant correlation between the drainage density and erosion that corresponds with Ahmadi et al. [3] results, which examines the relationship in Sarvelayats watershed. On the other hand; we can estimate the rate of erosion with using of drainage density.

\section{Reference}

[1] Pedro, A. B., Gerardo A. R., Erik D. Z. \& Hernán R. Stenta. Simulation of erosion-deposition processes at basin scale by a physically-based mathematical model. International Journal of Sediment Research, 25, 2010.

[2] Germanoski, D., Hardy, S. \& Wilson, J., Comparison of Drainage Densities in Carbonate vs Shale/Slate, Eastern Pennsylvania, Proc. Awra Spring Speciality Conference New Orleans, 2012.

[3] Ahmadi, H., A, Kelarestaghi, \& N. Mashhadi, Survey of erosion in geomorphological facies and its relationship with drainage density in Sarvelayat watershed. Iranian Journal of Natural Resources .Vol 60, No 4, 2007.

[4] Mishra, S., Spatial Analysis Of Drainage Network For Ground Water Exploration In River Basin Using GIS And Remote Sensing Techniques: a 
Case Study Of Tons River In Allahabad, India Journal of Environmental Research And Development, Vol. 7, No. 3, 2013.

[5] Zhang, X., Wu, B., Ling, F., Zeng, Y., Yan, N. \& Youan, C., Identification of priority areas for controlling soil erosion. Catena 83, 2010.

[6] Shyamal, D. \& Suvendu, R., Determination of erosion surfaces and stages of evolution of Sangr drainage basin in Giridih district, Jharkhand, India. International Journal of Geomatic and Geoscience, Volume 3, No 1. pp. 6373, 2012.

[7] Ross W. Irwin \& Hugh R. Whiteley. Effects of Land Drainage on Stream Flow. Canadian Water Resources Journal, Vol. 8, No. 2, 2013. 